\title{
Beyond population growth: bringing connection, renewal and agency into regional development
}

\author{
Fiona McKenzie* Victorian Government \\ Fiona McKenzie Orange Compass \\ Fiona McKenzie University of Western Australia \\ *Corresponding author. Email: fiona.mckenzie@delwp.vic.gov.au. Address: Department of \\ Environment, Land, Water and Planning, PO Box 500, East Melbourne, Vic 8002, Australia \\ Paper received 9 August 2021; accepted 30 October 2021; published 29 November 2021
}

\begin{abstract}
Background

Boosting the population growth of towns and cities across regional Australia has long been a popular aspiration. However, the reality of many regional locations is long-term population decline.
\end{abstract}

Aims

Regional development has been underpinned by a growth paradigm which conflates population growth with success. This article explores how some regional communities have experienced renewal, fostered innovation, and enhanced community wellbeing without population growth.

\section{Data and methods}

A mixed methods approach informs this paper. Five case studies are used to illustrate ways in which regional communities can experience successful economic and social outcomes without population growth. Literature is provided for context and empirical data are used to illustrate key features of the selected towns.

\section{Results}

The case studies reveal themes of connection, place, agency and wellbeing which contribute to 'successful' communities. For example, developing connections with a wider network within the region or across sectors enables economic growth through innovation, irrespective of population growth.

\section{Conclusions}

Being able to respond to, or take advantage of, change is an important element in regional development and one which creates community renewal and wellbeing even if not population growth.

\section{Key words}

Population growth; population decline; regional Australia; community wellbeing. 


\section{Introduction}

Boosting the growth of towns and cities across regional Australia has long been a popular, if unsuccessful, strategy (Guaralda et al. 2020). This strategy has been fuelled by the growth-oriented paradigm underpinning the economic conceptualisation of regional development (Fudge et al. 2021). However, this paradigm does not address the reality of many regional locations which have an older age structure and little in migration - two demographic factors which make population growth unrealistic. The growth paradigm also conflates economic growth and population growth with an underlying assumption that both forms of growth will lead to "success", a somewhat unclear objective which does not always consider aspects of community or individual wellbeing.

This article examines ways in which regional communities can experience renewal, foster innovation, and enhance community wellbeing without population growth. Case studies have been selected to illustrate this. While literature is provided for context and empirical data are used to illustrate key features of the selected towns being discussed, the paper also draws upon the combined experience of the authors, each of whom has had more than 20 years' experience in regional development and research. A mixed methods approach therefore informs this paper.

The selected communities have had to adapt to economic and social change over the past four decades and all have had stable or declining rates of population growth. Their experience can inform debates about the elements of regional development that matter most to communities: connection, agency, wellbeing, renewal, and sustainability. The case studies presented in this article focus on towns in which there has been limited or no population growth over recent decades (Figure 1). Yet in terms of economic development, social diversification, and wellbeing, each may be regarded as successful. There is no single approach that can fully explain such success. For Birchip, networks, information flows and innovation are key ingredients. Katanning and Nhill have both experienced major changes in social profile which have created new economic opportunities, while in Lake

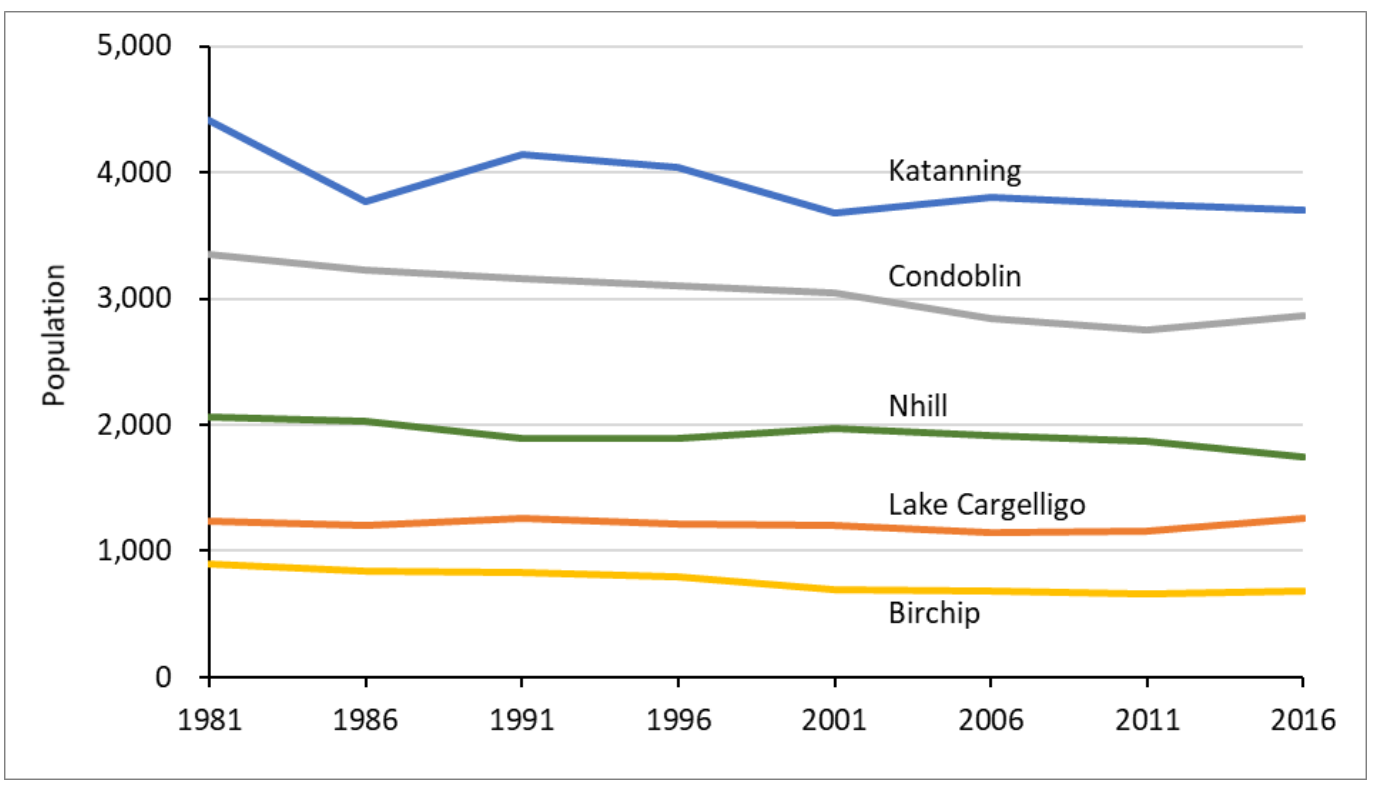

Figure 1: Population of selected case study towns, 1981 to 2016

Source: ABS Census data, Urban Centre and Localities. 
Cargelligo and Condoblin community-led place-based development has increased local agency to identify and achieve their objectives for local wellbeing.

\section{Networks and connections}

\subsection{Literature}

The Australian settlement system is characterised by large state capital cities which contain high proportions of their states' population. Nevertheless, Australian settlement patterns are not just about capital cities. There are hundreds of small and medium sized towns across the country. Some have experienced population growth, others decline, and others have shown little change - at least in terms of overall population numbers.

Regional economic development narratives that highlight population growth as a key element of success would seem to imply that lack of population growth means economic or social demise. The recognised role of large cities as economic drivers in modern economies further entrenches this view. Because large cities are seen to have high levels of human capital, dense networks and information spillovers, they are seen as being a driving force of innovation and development (Florida 2002; Scott \& Storper 2003). Very few authors have challenged the view that large cities are the only places where innovation can occur. Shearmur $(2012,2015)$ is an exception in this regard. He challenges the notion that innovation always requires physical proximity. Furthermore, proximity itself may mean different things apart from physical closeness. It may include social, organisational, or cultural connections which form strong networks across a variety of distances (Shearmur 2015). This fluidity of proximity is further explored in a range of academic works (Rallet \& Torre 1999; Blanc \& Sierra 1999; Urry 2003a; 2004; Boschma 2005a, 2005b; Kesselring 2014) which examine the increasing levels of actual and virtual mobility in the modern world which change the nature and perception of distance and space. This is important for regional economic development because increasing connectivity has the potential to widen networks and overcome many of the disadvantages of distance or remoteness. An outcome is that "[t]hings are made close through these networked relations" (Hannam et al. 2006 p. 14, original emphasis).

Networks such as these highlighted above are clearly advantageous in a dynamic modern economy, both for businesses and individuals. However, such dynamism is not traditionally associated with small rural communities. Many rural communities are characterised by strong ties - bonding social capital that can create resilience, but also parochialism. From a sociological point of view, communities with strong bonds of social capital may be seen to have key strengths in terms of mutual support (Granovetter 1983). These 'strong ties' connect individuals through frequent contact and similar interests or values. In contrast are 'weak ties' which can be thought of as acquaintances people seen or contacted infrequently and perhaps with fewer interests in common. Granovetter, in his seminal 1973 paper, showed that, while strong ties provide cohesion for a particular group or community, their ultimate weakness is in the insularity and isolation which can occur as a result of that group having few contacts with other worlds or world views (Granovetter 1973). This type of insularity presents particular problems in a rapidly changing world where it can rapidly lead to isolation and detachment from mainstream events (economic, social or political). By contrast, 
individuals who have many weak ties are better placed to defuse new ideas since their ties can bridge different communities across many locations (Granovetter 1973).

The implication for non-metropolitan communities is that links with the nonlocal are likely to lead to new ideas and perspectives (Rallet \& Torre 1999; Fitjar \& Rodríguez-Pose 2011). These in turn can fuel innovation and future development within the region. Digital technology can maintain weak-tie relationships across broad networks (McKenzie 2017). These 'weak ties' are important for development and innovation. It is important to highlight here the growth of distributed knowledge networks, as distinct from social networks, which reach far beyond the local due to virtual connectivity. Research conducted in Australia found that those undertaking transformational change had more far-reaching information and knowledge network connections yet less extensive social links to family, friends and colleagues compared with incremental-scale adaptors. Strong access to knowledge and weak social ties actually increased the ability to facilitate action that differs from established social norms (Dowd et al. 2014).

Bringing these ideas together - connectivity, fluid concepts of proximity, and the importance of weak social ties but strong knowledge networks - has important implications for regional development. Work by Fitjar \& Rodríguez-Pose (2011) highlighted the factors that made regional businesses in the peripheral region of Southwest Norway wealthy and innovative. Local factors such as collaboration, agglomeration and clustering were not found to be significant. Instead, it was international networks and long-distance cooperation which accounted for much of the product innovation occurring in the region (Fitjar \& Rodríguez-Pose 2011). The education levels and attitudes of managers were also found to be important in the creation and retention of international networks, suggesting that human capital and individual initiative can play a significant role in bringing innovative practices to peripheral regions.

Many of these managers had been forced to go elsewhere in Norway for their higher education due to the absence of a local university. This experience had expanded their horizons, experience and networks which could continue to be used upon their return to a more peripheral location. The general open-mindedness associated with the life experience of moving in order to improve their level of education can be considered as a fundamental factor in overcoming place-boundedness in their work relationships (Fitjar \& Rodríguez-Pose 2011).

These alternative views to the mainstream narrative of city-based innovation open interesting avenues for considering the prospects for human capital and economic potential in regional Australia. The pattern of moving from regional areas to capital cities for education is relatively common. One estimate suggests that around half of school leavers from non-metropolitan areas move to capital cities and $29 \%$ of this group of leavers have returned to non-metropolitan areas by the age of 23 (DELWP 2016). Others may well return to non-metropolitan areas at later ages. This pattern of spending time in a capital city and then returning to non-metropolitan areas of Australia, has the potential for links to be made in the way that Fitjar \& Rodríguez-Pose (2011) envisage. Not only have such individuals gained human capital in a formal sense through education and work experience, but the networks gained while in the city can continue to be of benefit for future regional development. The city of Orange in NSW shows how mobility and networks have been used to increase economic development opportunities for local growth. Research undertaken by McKenzie (2015) found that many of the town's leaders expressed the value of having left the city to gain 
education, skills or experience, then bringing those benefits back to the community (McKenzie 2015). This type of mobility has been found to play an important role in regional development in Australia as well. Work by Plowman et al. (2003) found that more innovative communities had higher proportions of residents who had lived elsewhere.

Social and professional networks are important for regional development in that highly skilled people within a network can be viewed as "potential resources to be mobilised and capitalised at a distance" (Rerat 2016 p. 280). In other words, they need not be geographically close to provide a potential economic benefit. Such networks can deliver "exponential increases in output (and rewards or wealth) that are spread throughout a network of relationships within which a variety of enterprises are located and operate" (Urry 2003b p. 53, original emphasis).

\subsection{Case study: Birchip}

Even small towns with little or no population growth can succeed through connectivity and local initiative. The town of Birchip in Victoria's Mallee region is small, with an enumerated population of 676 recorded at the 2016 Census. The nearest centre with more than 2,500 people is located more than 100 kilometres away. Yet the connectivity of Birchip to the outside world is evident through innovative farmers and businesses in the field of dryland agriculture. The Birchip Cropping Group was established in the early 1990s as a way to improve farming research, knowledge and practice across the region. Its stated mission is "to improve the prosperity of Australia's broadacre farmers through applied science-based research and extension" (BCG 2020 p. 1). The group delivered over 80 projects in 2019-20 with the aim of delivering benefits to its members through attracting research and extension funding which benefits farmers, communities and the environment in the local region (BCG 2020).

The Birchip Cropping Group has been at the forefront of applying new technologies and farming practices and has developed a network of more than 50 investors and collaborators across government, universities, and private enterprise. The BCG's investors and collaborators include a wide range of organisations and sectors, both local and global as shown in Table 1. The local primary to Year 12 (P-12) College has developed close links between its curriculum and the local economy. Its 'structured workplace learning' program provides opportunities for students to combine job experience in agriculture with secondary school study (Batters 2021). The development of digital skills for modern precision agriculture involves gaining experience with geographical information systems (GIS), variable rate technology (for application of water fertilisers and pesticides), soil sensors, yield monitors and remote sensing using drones. Understanding these technologies is of particular benefit for students' education and the future of the local economy (BCG 2018). 
Table 1: Number of investors and collaborators with Birchip Cropping Group by sectors and locations, 2019-20

\begin{tabular}{lclc}
\hline Sector & No. & Location & No. \\
\hline Research / Academia & 17 & Interstate & 28 \\
Business & 8 & Victoria & 24 \\
State Government & 8 & Local (within Birchip) & 2 \\
Industry Association & 6 & Overseas & 1 \\
Philanthropic & 4 & & \\
Secondary Education & 3 & & \\
Federal Government & 3 & & \\
Peak Body & 2 & & 55 \\
Other & 4 & & \\
\hline Total & 55 & Total & \\
\hline
\end{tabular}

Source: Compiled from data in BCG 2020, p. 9.

\section{Renewal}

\subsection{Literature}

For much of the twentieth century, many rural-based communities enjoyed population growth. Public investment in transport infrastructure, utilities and social services, along with tariffs and import restrictions supported and protected local industry. Trade liberalisation policies introduced in the mid-1980s significantly affected their local economies (Tonts \& Haslam McKenzie 2005). The restructuring of the Australian economy caused many services in rural communities to be rationalised and centralised in larger, regional centres, with many people in small towns following the services. Depressed commodity prices and increased costs of farm inputs in the 1980s and 1990s triggered many to leave agriculture and small communities struggled. Structural changes were starting to create major changes in rural Australia. Farms were, on average, larger and more productive, but fewer workers were needed as capital intensive methods superseded labour intensive farming practices (Stayner \& Reeve 1990; Garnett \& Lewis 1999). Declining terms of trade in the agricultural sector also fuelled the trend towards consolidation, as productivity could be increased through expansion into larger farms (Barr 2009; Smailes et al. 2019).

The social composition of the countryside was also changing, and economic activities broadened from productive to consumptive activities such as second homes and tourism uses (Smailes 2002; McKenzie et al. 2008). This growing complexity in rural land use was variously termed the 'postproductivist' countryside (Wilson 2001; Argent 2010) or 'multifunctional countryside' (Smailes 2002). Increasing diversity of land use was both fuelled by, and generated, increasing temporary mobilities. Importantly, these economic changes were happening at a time of increasing personal mobility. Car ownership and improvements in road quality played a major factor in changing population distribution in regional areas. Small towns which had previously offered a range of basic services could now be bypassed as people were able to access a wider geographical area. This favoured larger centres where businesses could increasingly gain access to a wider market. Conversely, businesses in small towns saw a contraction in demand for their goods and services. 
As regional Australia became increasingly integrated into global economic systems, a parallel process of economic policy reform was occurring (Tonts \& Haslam McKenzie 2005; Beer 2012). In the 1980s, the Hawke and Keating governments led a period of major economic reform which effectively ended the high levels of protectionism in Australian trade and industry. Fiscal reforms, such as floating the Australian dollar and allowing entry of foreign banks into the country, made Australia much more open to the global economy. The subsequent coalition government undertook further economic reform from the mid-1990s. This neoliberal agenda continued through the 2000s and was characterised by fiscal conservatism, labour-market deregulation, mutual-obligation pacts, introduction of a national competition policy, and a move away from the welfare state ( $O^{\prime}$ Neill \& Fagan 2006; Hogan \& Young 2015).

Trade liberalisation policies significantly affected their local economies (Tonts \& Haslam McKenzie 2005). The restructuring of the Australian economy caused many services in rural communities to be rationalised and centralised in larger, regional centres, with many people in small towns following the services. Depressed commodity prices and increased costs of farm inputs triggered many to leave agriculture and small communities struggled throughout the 1980s and 1990s (Smailes et al. 2019). Despite these challenges, however, some communities responded with innovative ideas for renewal.

\subsection{Case study: Nhill}

The town of Nhill in western Victoria has experienced population decline over several decades. In 2016 the town's population was 1,752 according to the census, down from 1,879 in 2006 (ABS 2016). Despite the lack of growth in total population, the town has seen a major change in its composition over the period. The proportion of overseas-born has doubled from $7 \%$ to $14 \%$ during the decade (ABS 2016). Since the late 2000s, the resettlement of refugees from Myanmar has created significant change in the town. The resettlement was driven largely by the owner of a local food processing plant who was seeking to expand operations. More than 160 refugees have settled in the district with around 30 children enrolled in local schools. The local economic benefit of the Karen refugees has been estimated at $\$ 40$ million by Deloitte Access Economics (AMES \& Deloitte 2015).

Clearly, this influx of new people has added to the local labour force, school population and ethnic diversity of the town. While it may have slowed the rate of decline of the town's population, it has not created population growth. Structural population decline has played out over half a century. Any turnaround may take as long to achieve. Nevertheless, Nhill has gained a great deal through refugee settlement. Regeneration can occur through social and economic change rather than in an increase in overall numbers.

\subsection{Case study: Katanning}

The Shire of Katanning is a municipality in Western Australia, $286 \mathrm{~km}$ south-east from Perth. Historically, agricultural production, particularly sheep and wool industries, were central to the economy. Katanning was not immune to the challenges, already cited, presented by Australia's engagement with global markets and the commitment to a neoliberal policy agenda. Katanning experienced hardship and struggled to make headway for almost two decades as farmers took advantage of their neighbours' departure from the industry and aggregated their properties to optimise economies of scale. Many young people did not see a future for themselves and they too left, causing a general ageing of the population, especially in rural communities (Tonts et al. 2008). 
Nonetheless, the industry profile of the Katanning local government area continues to be dominated by agriculture however two key investments have diversified local employment in the industry and created a sense of renewal.

The Katanning abattoir was established in the 1970s and, after restructuring in 1999, it became a producer-owned and controlled co-operative which has thrived, unlike many others across regional Western Australia. The abattoir pursued a niche in the meat market by focusing on premium quality lamb slaughtered in compliance with Halal practices, opening up a lucrative international market which has continued to expand. This strategy transformed the local community, with several Malay families recruited from the Cocos and Christmas Islands to perform the Halal slaughtering. Subsequent family groups followed and the business grew. As early as 1975, the Muslim community built a mosque in the town, the first in regional Western Australia. This and the promise of semi- and unskilled work were pull factors for arrivals and there has been a steady flow of migrants and refugees who have subsequently settled in the Shire. In 2020, the local shire boasted that more than 45 different nationalities live in the local government area (WALGA 2019). While the social adjustment has not always been easy because of cultural or language differences, the social change has enlivened Katanning and supported the local economy.

Another innovation in Katanning was the 2014 replacement of the former sheep saleyards with a state-of-the-art covered facility capable of trading 1.5 million sheep annually. The roof covers more than a hectare of stockyards. Located alongside this are offices and amenities for farmers, stockmen and truck drivers who need to stay overnight. The enhanced conditions have been the catalyst for a new, unexpected tourism attraction with visitors coming to watch the rapid-fire sales routines and the dogs working in the yards and trucks each Tuesday and Wednesday (Shire of Katanning 2021). The new canteen has also become a regular destination for visitors to rub shoulders with the stockmen and many local farmers, with up to three sittings on Tuesday evenings and throughout the sale day each Wednesday. It has become busy enough that local women have now started a catering business running the canteen. Hence what was part of the traditional primary sector has spawned a number of service industries related to accommodation, hospitality and tourism - all of which have been expanding economic sectors in recent decades and which offer a range of employment opportunities.

When the saleyards were constructed, the facility adopted a number of environmental and laboursaving innovations which generated other new businesses. Manure from the saleyards flows into holding tanks and subsequently collected for drying and processing by a local migrant family who now employ additional labour. The product is sold to horticultural wholesalers and nurseries across southern Western Australia. The saleyard roof covers $44,000 \mathrm{~m}^{2}$ and rainfall is collected, stored, treated, then gravity pushed to a new lake, arboretum and botanic garden in the centre of the town, transforming a low lying, unsightly area to prized real estate (Shire of Katanning 2021).

The revival of the sheep industry in Katanning inspired a local entrepreneur to buy the dilapidated historical flour mill in the centre of the town. The local shire sold the property for one dollar in 2014, on condition that the new owner restore the building (Acott 2018). Considerable funds were invested to renovate it as a high-end hotel with the Dome Café opening at street level in 2019. The business plan took account of Katanning's location in the centre of the Great Southern region with no other accommodation like it within at least two hour's drive of the town. In addition to the nascent sheep 
saleyard attraction, Katanning is located midway between Perth and Albany with two national parks and a well-established wine region less than an hour away. Despite the obvious financial set back associated with COVID 19 in 2020, the domestic tourism market boom in 2021 has certainly compensated with occupancy rates being steady throughout 2020-2021 (The Premier Mill 2021).

Katanning, like Nhill, struggles to maintain its population base because of structural population ageing, yet the social profile and economic prospects of both towns have experienced renewal through migration, social diversity and innovative industry development. Regeneration can occur through social and economic change rather than in an increase in overall population numbers.

\section{Place-based approaches}

\subsection{Literature}

In the literature, there has been a move from an economic development focus to a more holistic sustainable development focus when considering regional development (Fudge et al. 2021), however formal regional policies at state, federal or even local government level still have an assumption (implicit or explicit) that population growth is an essential part of regional development. It is increasingly acknowledged that, in addition to job creation, wage rates and other quantitative measures of economic development, other factors such as sense of place, social capital and social and environmental wellbeing are also important (Plummer et al. 2018).

Place-based policies, as the term implies, have a focus on specific locations or regions. But as noted by Beer et al. (2020)

they represent far more than just a label for already established programmes of government activity, or the concentration of public sector resources in specific locations. Place-based policies embody an ethos about, and an approach to, the development of economies and society that acknowledges that the context of each and every city, region and rural district offers opportunities for advancing well-being (Beer et al. 2020 p. 12).

While recognising that there are many different types of place-based approaches, here we are referring to collective, community-led initiatives. They are characterised by collaboration, community-driven agency and ownership at their heart. Connection and agency are central themes which affect the success of place-based initiatives - they give power to the community to guide their own change agenda. It is critical to note that "place" is not homogenous. It is something that is encountered and experienced differently by different people in the community (Mackay et al. 2021; Rainnie 2021). Community is also not homogenous, yet it remains central to place-based approaches.

Such approaches require support from skilled local teams that help to create meaningful connections and partnerships across the community, businesses, local service providers, agencies and funders. These teams recognise that there is no 'one size fits all' recipe and ensure that any action taken is the right action for that community's unique context. Key features of good community-focussed placebased development initiatives include:

- fostering cross-sector collaborations that harness local resources and place community priorities at the centre; 
- implementing timely and targeted responses that meet the specific needs of community, especially those most vulnerable;

- creating trusted relationships as an intermediary between the wider system and local communities;

- empowering the community through local participation and representation; and

- drawing upon local knowledge, community networks, and relationships to help people deal with uncertainty.

All of this is built upon a foundation of connection and trust amongst different community networks (formal and informal) that has taken time and effort to build, underpinned by appropriate social infrastructure to support collaboration.

\subsection{Case study: Growing Lachlan (Condobolin and Lake Cargelligo)}

Growing Lachlan has been a pioneer of community-led place-based initiatives in NSW. Over six years, Growing Lachlan has developed into an important community asset, with trusted relationships that allow it to play a range of crucial roles. The initiative began in 2014 with a request from Lachlan Shire Interagency Groups for a dedicated resource to improve communication and collaboration between services, increase service uptake and influence government funding to address local needs. Over the first year, it developed into a community initiative that sought to identify and action opportunities that locals see as important to build on the Shire's strengths (Dusseldorp Forum 2020).

Across 2015 and 2016, the team gathered data on key indicators of community wellbeing, conducted surveys and held a series of community conversations to understand how the community is faring, and identify key challenges and opportunities across the Shire. The information came together in the Growing Lachlan report which outlines the community's shared priorities towards:

1. Investing in community renewal

2. Supporting economic sustainability and development

3. Improving community safety and crime prevention

4. Taking care of older and younger generations and

5. Strengthening cultural recognition, respect and genuine participation. (McKenzie 2019).

Since 2017, Growing Lachlan has worked with all Shire communities, supporting a wide variety of people, groups and services to activate their ideas towards advancing the community priorities. It is not a service provider itself, but rather plays a unique linking and supporting role, and encourages new ways of working and collaboration, challenging groups to think and act on how things can be done better, and better together.

In addition to their Growing Lachlan work over the last two years, the team was instrumental in the development of the Regional Innovators' Network, an award-winning model of regional capacity building, with TACSI and CAPP Dubbo (RIN 2021). Growing Lachlan now holds sophisticated skills in authentic community engagement, community co-design and facilitation methods.

It is growing a culture of innovation in the Lachlan Shire by supporting local groups to 'test and try' new approaches to addressing community priorities. Growing Lachlan has supported, partnered with and in some cases catalysed a range of locally specific innovations that have improved outcomes for individuals, families and the wider community. 
More and more communities are looking towards models of place-based collaboration to address their development needs (McKenzie 2020). Adopting place-based collaborative development approaches also improves alignment of government and community aspirations, leading to more efficient and productive allocation of resources (Taylor et al. 2017). Such initiatives do need to be adequately resourced. Empowerment of community is a necessary but not sufficient move towards a different destiny (Rainnie 2021). Furthermore, the challenges of community development in small regional towns including resource scarcity, volunteer burnout and serious socioeconomic disadvantage for population segments may still need to be addressed.

\section{Conclusions}

For communities facing population stability or decline, there are alternative ways to approach regional development and measure "success". The case studies presented in this article show ways in which communities are more than simply the total number of people living there or whether that number is increasing or decreasing. Instead, the selected case studies reveal themes of connection, place, agency and wellbeing. These factors contribute to 'successful' communities even in the face of population decline. For example, developing connections with a wider network within the region (Condobolin and Lake Cargelligo) or across sectors (Birchip) enables economic growth through innovation, irrespective of population growth.

Place-based approaches are emerging as a new way of unlocking local agency and capability. There has been growing interest in the question of agency, particularly at the local level. This has often materialised in the form of what has become known as place- based leadership (Rainnie 2021). It is important to rethink existing assumptions about regional development through these lenses of place and local experience (Fudge et al. 2021).

When talking about agency, it is important to acknowledge the challenge of agency in the context of regional economies exposed to global fluctuations, and how local businesses and firms usually sit in a very low position on most value chains. Regional policy narratives have been somewhat contradictory in this regard. On the one hand, rural communities are encouraged to be part of the global economy for their successful development, while on the other hand they are told that the future is in their own hands with local leaders expected to steer the fortunes of their communities (Plummer et al. 2018).

It is true that communities may not have full agency over their futures. Global forces - economic and social - play an important role in shaping the fortunes of regional communities. Yet, as shown in the case studies in this paper, being able to respond to, or take advantage of, change is an important element in regional development and one which creates community renewal and wellbeing even if not population growth.

\section{Key messages}

- Regional development has been underpinned by a growth paradigm which conflates population growth with success.

- Seeking population growth has been a popular regional policy aspiration, however, the reality of many locations is long-term population decline. 
- Some towns with limited or no population growth can be successful by utilising networks, information flows and community-led place-based development.

- Being able to respond to, or take advantage of, change is an important element in regional development and one which creates community renewal and wellbeing even if not population growth.

\section{Disclaimer}

The views expressed in this paper are those of the authors and should not be regarded as representing the views of the Victorian Government or the Department of Environment, Land, Water and Planning.

\section{References}

ABS (2016) Census of Population and Housing 2016, Australian Government, Canberra. https://www.abs.gov.au/websitedbs/censushome.nsf/home/2016

ABS (various years) Census of Population and Housing, Australian Government, Canberra. https://www.abs.gov.au/census/find-census-data/historical. Accessed on 9 July 2021.

Acott K (2018) History of 127 -year-old Katanning flour mill preserved as luxury Premier Mill Hotel, The West Australia. https://thewest.com.au/news/tourism/history-of-127-year-old-katanning-flourmill-preserved-as-luxury-premier-mill-hotel-ng-b88844136z. Accessed on 17 November 2021.

AMES (Adult Multicultural Education Services) and Deloitte Access Economics (2015) Small towns big returns. Economic and social impact of the Karen resettlement in Nhill.

https://www2.deloitte.com/content/dam/Deloitte/au/Documents/Economics/deloitte-aueconomics-small-towns-big-returns-nhill-resettlement-270415.pdf

Argent N (2010) From pillar to post? In search of the post-productivist countryside in Australia. Australian Geographer 33(1): 97-114. https://doi.org/10.1080/00049180220125033

Barr N (2009) The House on the Hill: The Transformation of Australia's Farming Communities. Land and Water Australia in association with Halstead Press, Canberra.

Batters J (2021) Structured workplace learning at BCG. Birchip Cropping Group News 28 June 2021. https://www.bcg.org.au/structured-workplace-learning-at-bcg/. Accessed on 17 October 2021.

BCG (Birchip Cropping Group) (2018) Agricultural STEM in classrooms. Birchip Cropping Group News 27 February 2018. https://www.bcg.org.au/agricultural-stem-in-classrooms/. Accessed on 17 October 2021.

BCG (Birchip Cropping Group) (2020). Annual Report 2019-20. https://issuu.com/iemma35/docs/bcg annual report 201920-bcg-39jctn2. Accessed on 22 June 2021.

Beer A (2012) The economic geography of Australia and its analysis: from industrial to post-industrial regions. Geographical Research 50(3): 269-281. https://doi.org/10.1111/i.1745-5871.2012.00771.x

Beer A, McKenzie F, Blažek J, Sotarauta M, \& Ayres S (2020) Every Place Matters: Towards Effective PlaceBased Policy. Taylor and Francis. https://doi.org/10.4324/9781003110118

Blanc H \& Sierra C (1999) The internalisation of R\&D by multinationals: a trade-off between external and internal proximity. Cambridge Journal of Economics 23(2): 187-206. https://doi.org/10.1093/cje/23.2.187

Boschma R (2005a) Role of proximity in interaction and performance: conceptual and empirical challenges. Regional Studies 39(1): 41-45. https://doi.org/10.1080/0034340052000320878 
Boschma R (2005b) Proximity and innovation: a critical assessment. Regional Studies 39(1): 61-74. https://doi.org/10.1080/0034340052000320887

DELWP (Department of Environment, Land, Water and Planning) (2016) Attraction and Retention. Education and Labour Force Pathways of Metropolitan and Regional School Leavers in Victoria. Summary of findings from the ARC (Australian Research Council) Linkage Project LP120100212, undertaken by the University of Queensland; Victorian Government; Graduate Careers Australia, and Latrobe University Bendigo, report prepared by Forward Policy and Research Branch DELWP, Victorian Government, Melbourne.

https://www.planning.vic.gov.au/ data/assets/pdf file/0033/97683/Attraction-and-Retention2016.pdf

Dowd A, Marshall N, Fleming A, Jakku E, Gaillard E, \& Howden M (2014) The role of networks in transforming Australian agriculture. Nature Climate Change 4: 558-563.

https://doi.org/10.1038/nclimate2275

Dusseldorp Forum (2020) Place based resilience: Community driven response and recovery in a time of COVID-19. Dusseldorp Forum, Sydney. https://www.dusseldorp.org.au/wp-

content/uploads/2020/11/Place-Based-Resilience Community-Driven-Response-and-Recovery-ina-Time-of-COVID 19.pdf

Fitjar R \& Rodríguez-Pose A (2011) Innovating in the periphery: firms, values, and innovation in southwest Norway. European Planning Studies 19(4): 555-574.

https://doi.org/10.1080/09654313.2011.548467

Florida R (2002) The economic geography of talent. Annals of the Association of American Geographers 92(4): 743-755. https://doi.org/10.1111/1467-8306.00314

Fudge M, Ogier E, \& Alexander K A (2021) Emerging functions of the wellbeing concept in regional development scholarship: a review. Environmental Science \& Policy 115: 143-150. https://doi.org/10.1016/i.envsci.2020.10.005

Garnett A \& Lewis P (1999) Trends in rural labour markets. The Centre for Labour Market Research, Discussion Paper 99/9, Murdoch University, Perth.

Granovetter M (1973) The strength of weak ties. American Journal of Sociology 78(6): 1360-1380. https://doi.org/10.1086/225469

Granovetter M (1983) The strength of weak ties: a network theory revisited. Sociological Theory 1: 203233. https://doi.org/10.2307/202051

Guaralda M, Hearn G, Foth M, Yigitcanlar T, Mayere S, \& Law L (2020) Towards Australian regional turnaround: insights into sustainably accommodating post-pandemic urban growth in regional towns and cities. Sustainability 12.

Hannam K, Sheller M, \& Urry J (2006) Mobilities, immobilities and moorings. Mobilities 1(1): 1-22. https://doi.org/10.1080/17450100500489189

Hogan A \& Young M (2015) The making of rural and regional Australia: an introduction. In Hogan A and Young M (eds.) Rural and Regional Futures. Routledge; pp. 1-15. https://doi.org/10.4324/9781315775333

Kesselring $S$ (2014) Mobility, power and the emerging new mobilities regime. Sociologica 1(1): 1-30.

Mackay S, Klaebe H, Hancox D, \& Gattenhof S (2021) Understanding the value of the creative arts: placebased perspectives from regional Australia. Cultural Trends. https://doi.org/10.1080/09548963.2021.1889343

McKenzie F (2015) Understanding regional cities: combining quantitative and qualitative methods in case studies of Orange and Goulburn, NSW. Australasian Journal of Regional Studies 21(3): 303-322. https://www.anzrsai.org/assets/Uploads/PublicationChapter/Mckenzie-Final.pdf 
McKenzie F (2017) Keeping up with the Capital. How regional Australia has responded to economic and demographic change since the 1990s. PhD by Portfolio of Publications Applied Economics, University of South Australia Business School, School of Commerce.

McKenzie F (2019) Growing Lachlan: Community driven place-based change. Orange Compass, Sydney. https://www.orangecompass.com.au/images/Growing Lachlan Outcomes Report.pdf

O'Neill P \& Fagan B (2006) Geographical takes on three decades of economic reform in Australia. Geographical Research 44(2): 204-219. https://doi.org/10.1111/j.1745-5871.2006.00377.x

Plowman I, Ashkanasy N, Gardner J, \& Letts M (2003) Innovation in Rural Queensland: Why Some Towns Thrive While Others Languish. Main Report. University of Queensland Business School and Queensland Department of Primary Industries, Brisbane. https://cep.org.au/wpcontent/uploads/2021/03/Why-small-towns-prosper-1.pdf

Plummer P, Tonts M, \& Argent N (2018) Sustainable rural economies, evolutionary dynamics and regional policy. Applied Geography 90: 308-320. https://doi.org/10.1016/i.apgeog.2017.01.005

Rainnie A (2021) Regional development and agency: Unfinished business. Local Economy. https://doi.org/10.1177/02690942211023877

Rallet A \& Torre A (1999) Is geographical proximity necessary in the innovation networks in the era of the global economy? GeoJournal 49(4): 373-380. https://doi.org/10.1023/A:1007140329027

Rérat $P$ (2016) Migration and post-university transition. Why do university graduates not return to their rural home region? Geographica Helvetica 71(4): 271-282. https://doi.org/10.5194/gh-71-271-2016

RIN (Regional Innovators' Network) (2021) The Australian Centre for Social Innovation. https://regionalinnovation.com.au/about. Accessed on 20 July 2021.

Scott A \& Storper M (2003) Regions, globalization, development. Regional Studies 37(6/7): 549-578. https://doi.org/10.1080/0034340032000108697a

Shearmur R (2012) Are cities the font of innovation? A critical review of the literature on cities and innovation. Cities 29(S2): S9-S18. https://doi.org/10.1016/i.cities.2012.06.008

Shearmur R (2015) Far from the madding crowd: slow innovators, information value, and the geography of innovation. Growth and Change 46(3): 424-442. https://doi.org/10.1111/grow.12097

Shire of Katanning (2021) Katanning regional sheep saleyards.

https://www.katanning.wa.gov.au/explore/things-to-see-and-do/regional-saleyards.aspx. Accessed on 17 November 2021.

Smailes P (2002) From rural dilution to multifunctional countryside: some pointers to the future from South Australia. Australian Geographer 33(1): 79-95. https://doi.org/10.1080/00049180220125024

Smailes P, Griffin T, \& Argent N (2019) Regional Cities and City Regions in Australia: A Long-term Demographic Perspective. Springer. https://doi.org/10.1007/978-981-13-1111-6

Stayner R \& Reeve I (1990) 'Uncoupling': relationships between agriculture and the local economies of rural areas in New South Wales. Rural Towns Project, The Rural Development Centre, University of New England, Armidale, NSW.

Taylor B, Walton A, Loechel B, Measham T, \& Fleming D (2017) Strategic Foresight for Regional Australia: Megatrends, Scenarios and Implications. Canberra: CSIRO and the Australian Government Department of Infrastructure, Regional Development and Cities. https://doi.org/10.25919/5be328254aaa7

The Premier Mill (2021) Premier Mill Hotel: Our story, an icon restored. https://premiermillhotel.com/the-restoration-1. Accessed on 17 November 2021.

Tonts M \& Haslam McKenzie F (2005) Neoliberalism and changing regional policy in Australia. International Planning Studies 10(3-4): 183-200. https://doi.org/10.1080/13563470500378861 
Tonts M, Argent N, \& Plummer P (2012) Evolutionary perspectives on rural Australia. Geographical Research 50(3): 291-303. https://doi.org/10.1111/j.1745-5871.2011.00745.x

Urry J (2003a) Social networks, travel and talk. British Journal of Sociology 54(2): 155-176. https://doi.org/10.1080/0007131032000080186

Urry J (2003b) Global Complexity. Polity.

Urry J (2004) Connections. Environment and Planning D: Society and Space 22(1): 27-37. https://doi.org/10.1068/d322t

WALGA (Western Australian Local Government Association) (2019) Snapshot of multi-cultural Katanning. https://walga.asn.au/getattachment/Policy-Advice-and-Advocacy/People-and-Place/Accessibleand-Inclusive-Communities/Multicultural-Katanning-Presentation-WALGA-Oct-2019Final.pdf?lang=en-AU. Accessed on 2 June 2021. 